\title{
SURVEY CONCERNING INTERNATIONAL COMPUTER FILES OF ROAD ACCIDENTS
}

\author{
Michael Sivak and James O'Day \\ The University of Michigan Transportation Research Institute, Ann Arbor, MI 48109-2150, \\ U.S.A.
}

(Received 8 January 1988)

\begin{abstract}
A survey concerning international harmonization of accident reporting was distributed to 80 experts in accident reporting and analysis. Completed surveys were received from 50 persons in 13 countries; $74 \%$ of the respondents had more than 10 years of experience in the field of traffic safety. The main findings of this survey are: (1) $86 \%$ of the respondents think that an international computer file of disaggregated fatal-accident data would contribute to understanding of traffic safety, and $84 \%$ would use such a file. (2) An international non-fatal-accident filc was considered to be of value in research on human factors and accident causation $(60 \%)$, and in determining black spots in the road network $(57 \%)$. (3) Police was the most frequently mentioned source of data for both the fatal and non-fatal international data files. Nevertheless, fewer than one-quarter of respondents considered police as the suitable exclusive source of either data. (4) The majority view was that the data for both types of files should come from more than one agency. (5) In the case of the fatal-accident file, $78 \%$ of the respondents considered it important that the data be cross-checked with the public health records. (6) 'The 10 most useful variables for a fatal-accident file were traffic unit type (e.g. car), accident type (e.g. angle), road class, driver age, date/time of day, age of person killed, number of killed persons, number of injured persons, drinking or drug use, and restraint usage of person killed. (7) The analogous 10 variables for a non-fatal-accident file were accident type, traffic unit type, driver age, date/time of day, road class, extent of injury, number of injured persons, age of involved persons, number of involved persons, and seat location.
\end{abstract}

\section{INTRODUCTION}

This study is a continuation of a project on accident data standardization that was initiated in 1985. In the first phase of this research project (O'Day and Waissi 1986), personal discussions were held with many active researchers in this field. The principal findings from that study are as follows: (1) There are many inconsistencies among nations in both the threshold for accident reporting and in the detailed definition of variables, which make international comparisons difficult. (2) For fatal accidents these differences are less severe, and the set of fatal accidents should permit useful international comparison for some variables. (3) Definition of variables (particularly injury and vehicle damage scales) for in-depth accident investigations is reasonably consistent across national boundaries, and data files based upon these investigations may be useful in studies of such international topics as vehicle standards. Differences in coverage for in-depth studies make it difficult to compare accident frequencies among nations.

The present study consisted of a structured survey concerning desirable aspects of standardized accident reporting. Towards this goal, responses were sought from 80 researchers and experts in North America, Europe, Japan, and Australia.

\section{QUESTIONNAIRE}

The items in the questionnaire belonged to four categories: background of the respondent, fatal-accident files, non-fatal-accident files, and in-depth accident files.

\section{RESPONDENTS}

A written questionnaire was sent to 80 researchers and experts in accident reporting and analysis. A total of 50 persons completed the questionnaire, a response rate of $63 \%$. Table 1 presents a tabulation by country of distributed and completed questionnaires. 
Table 1. Tabulation of distributed and completed questionnaires by country

\begin{tabular}{l|c|c}
\hline \multicolumn{1}{c|}{ Country } & Distributed & Completed \\
\hline U.S.A. & 10 & 7 \\
United Kingdom & 7 & 6 \\
Sweden & 7 & 5 \\
Switzerland & 6 & 5 \\
Canada & 8 & 4 \\
West Germany & 7 & 4 \\
Australia & 6 & 4 \\
Japan & 6 & 4 \\
Finland & 5 & 4 \\
The Netherlands & 5 & 3 \\
France & 4 & 2 \\
Italy & 4 & 1 \\
Spain & 3 & 1 \\
Belgium & 2 & 0 \\
\hline
\end{tabular}

Table 2. Respondents' background

\begin{tabular}{|c|c|}
\hline Aspect & $\begin{array}{l}\text { Percentage } \\
\text { of Responses }\end{array}$ \\
\hline $\begin{array}{l}\text { Affiliation } \\
\text { Academia } \\
\text { Government } \\
\text { Industry }\end{array}$ & $\begin{array}{l}40 \\
30 \\
12\end{array}$ \\
\hline $\begin{array}{l}\text { Age } \\
\quad>30 \text { years } \\
>50 \text { years }\end{array}$ & $\begin{array}{r}100 \\
22\end{array}$ \\
\hline $\begin{array}{l}\text { Years of traffic-safety experience } \\
>10 \text { years } \\
>20 \text { years }\end{array}$ & $\begin{array}{l}74 \\
16\end{array}$ \\
\hline $\begin{array}{l}\text { Familiarity with the fatal traffic-accident } \\
\text { file for one's own country } \\
\text { Have used it }\end{array}$ & 80 \\
\hline $\begin{array}{l}\text { Familiarity with a fatal traffic-accident } \\
\text { file for a country other than one's own } \\
\text { Have used it }\end{array}$ & 36 \\
\hline $\begin{array}{l}\text { Familiarity with a non-fatal traffic accident file } \\
\text { Have used it }\end{array}$ & 88 \\
\hline $\begin{array}{l}\text { Familiarity with the U.S. National Accident Sampling System } \\
\text { Familiar with it }\end{array}$ & 58 \\
\hline $\begin{array}{l}\text { Extent of international research-related experience } \\
\text { Have used data from more than one country }\end{array}$ & 86 \\
\hline $\begin{array}{l}\text { Restricting the availability of accident data to particular } \\
\text { users or groups of users } \\
\text { In favor }\end{array}$ & 21 \\
\hline
\end{tabular}




\begin{tabular}{|c|c|}
\hline Aspect & $\begin{array}{l}\text { Percentage } \\
\text { of Responses }\end{array}$ \\
\hline $\begin{array}{l}\text { An international computer file of fatal traffic accidents would help the } \\
\text { understanding of traffic accidents }\end{array}$ & 86 \\
\hline Would use such a file & 84 \\
\hline $\begin{array}{l}\text { Data for such a file should come from } \\
\text { Police } \\
\text { Insurance companies } \\
\text { Medical community } \\
\text { More than one agency }\end{array}$ & $\begin{array}{r}24 \\
2 \\
0 \\
55\end{array}$ \\
\hline $\begin{array}{l}\text { Importance of cross-checking such data with data from public health (vital } \\
\text { statistics) records } \\
\text { Useful or necessary }\end{array}$ & 78 \\
\hline $\begin{array}{l}\text { Most useful variables in such a file [the respondents were asked to } \\
\text { check the } 10 \text { most useful variables - the list below was derived by } \\
\text { tabulating the } 20 \text { most frequently cited responses] } \\
\text { Traffic unit type (car, truck, motorcycle, pedestrian) } \\
\text { Accident type (angle, rear-end, pedestrian) } \\
\text { Road class (divided, two-lane) } \\
\text { Driver (or pedestrian/cyclist) age } \\
\text { Date/time of day } \\
\text { Age of person killed } \\
\text { Number of persons killed in accident } \\
\text { Number of persons injured (but not killed) in accident } \\
\text { Drinking or drug use in accident } \\
\text { Restraint usage of person killed } \\
\text { Weather condition } \\
\text { Seat location of person killed } \\
\text { Number of persons involved } \\
\text { Driver drinking or using drugs } \\
\text { Make and model of vehicle } \\
\text { Driver sex } \\
\text { Extent of injury } \\
\text { Light condition } \\
\text { Medical cause of death } \\
\text { Extent of injury to driver }\end{array}$ & $\begin{array}{l}85 \\
78 \\
59 \\
59 \\
57 \\
43 \\
41 \\
39 \\
37 \\
37 \\
35 \\
33 \\
30 \\
28 \\
28 \\
26 \\
26 \\
24 \\
24 \\
22\end{array}$ \\
\hline $\begin{array}{l}\text { Tolerable production delay for the availability of data } \\
\leq 1 \text { year } \\
1-3 \text { years }\end{array}$ & $\begin{array}{l}12 \\
40\end{array}$ \\
\hline $\begin{array}{l}\text { Preferred definition of fatality in terms of delay between the accident and death } \\
30 \text { day standard with analytical adjustment as required }\end{array}$ & 67 \\
\hline $\begin{array}{l}\text { Accidents of foreign nationals should be transferred (for statistical purposes) } \\
\text { to the country of normal residence }\end{array}$ & 4 \\
\hline Might actively support (by lobbying) the establishment of such a file & 64 \\
\hline Might actively contribute towards the establishment of such a file & 46 \\
\hline
\end{tabular}

\section{RESULTS}

The main results of the survey are presented in Table 2 (respondents' background), Table 3 (international fatal-accident file), Table 4 (international nonfatal-accident file), and Table 5 (international in-depth accident file). The information in Tables 2 through 5 is based on 46 to 50 responses per item. [Additional, secondary findings of this survey are included in a technical report (Sivak and O'Day 1987).]

\section{CONCLUDING COMMENTS}

The results of this international survey of researchers and experts support the value of an international fatal-accident file as a means of advancing our understanding of 
Table 4. Summary of responses concerning an international nonfatal-accident file

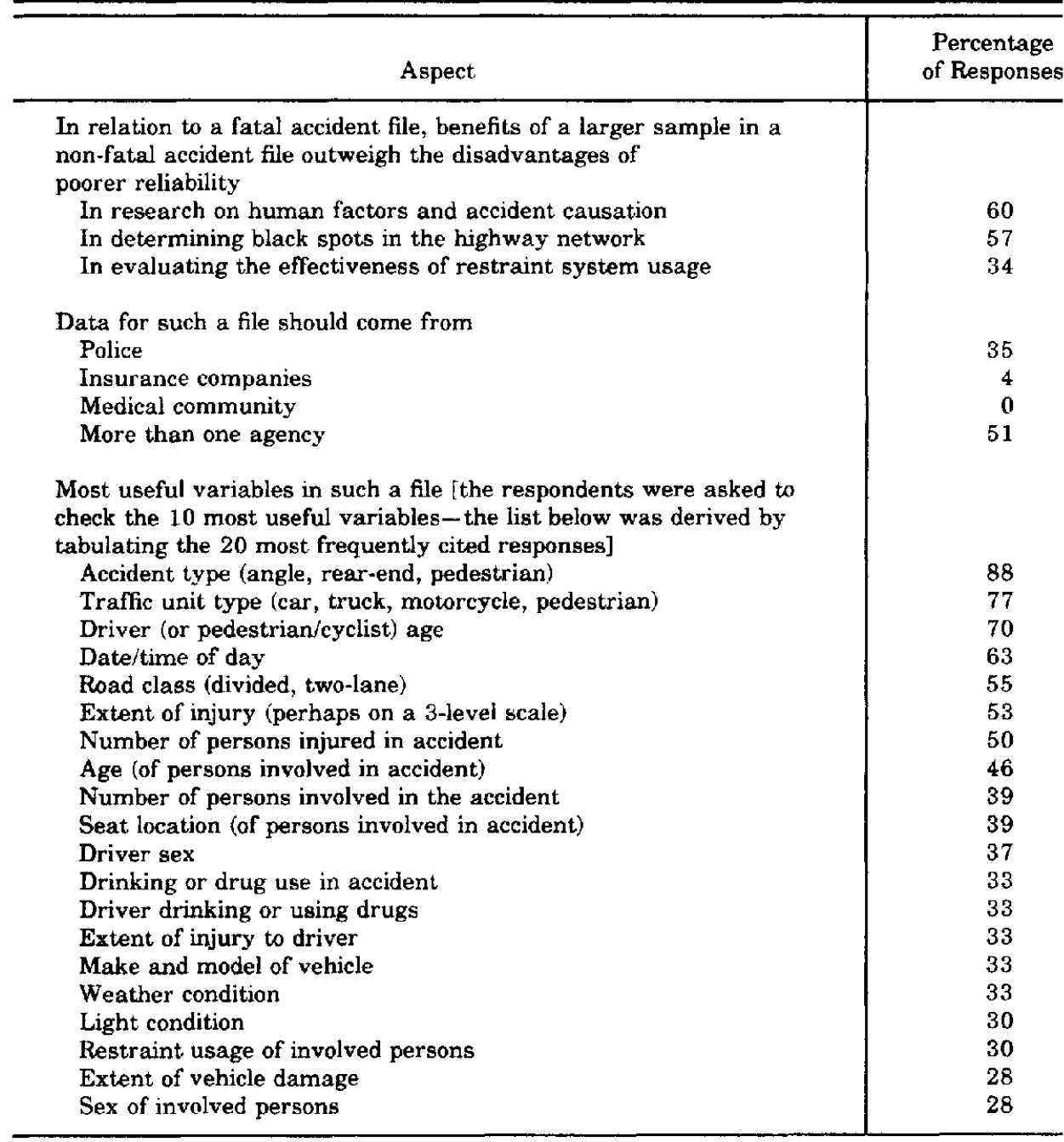

Table 5. Possible value of an international in-depth accident file (the possible aspects were provided in the questionnaire)

\begin{tabular}{l|c}
\hline \multicolumn{1}{c|}{ Aspect } & $\begin{array}{c}\text { Percentage } \\
\text { of Respondents }\end{array}$ \\
\hline Traffic accident causative factors & 67 \\
Effectiveness of restraint system usage & 46 \\
Incidence of driving under the influence of alcohol & 46 \\
Effectiveness of periodic motor vehicle inspections & 33 \\
Effectiveness of various types of windshields & 31 \\
\hline
\end{tabular}


traffic-safety issues. Furthermore, the majority of respondents would use such a file, and would actively support its establishment. The specific information obtained in this survey, concerning the desirable sources and content of such a file, could provide the foundations for a more concrete dialogue among the countries interested in establishing such a data bank.

Acknowledgement-This research was supported by the Motor Vehicle Manufacturers Association (MVMA).

\section{REFERENCES}

O'Day, J.; Waissi, G. R. Worldwide accident data standardization. Ann Arbor, MI: The University of Michigan Transportation Research Institute, Report No. UMTRI-86-48; September 1986.

Sivak, M.; O’Day, J. Survey concerning international harmonization of accident reporting. Ann Arbor, MI: The University of Michigan Transportation Research Institute, Report No. LMTRI-87-45; October 1987. 